\title{
Study of the Recharge Area on Water Basin Soil with Remote Sensing Method Using Satellite Imagery Landsat 7 ETM + and Geographic Information Systems ( GIS ) (Case Study : Pasuruan District )
}

\author{
Isniyatus Sholikhah ${ }^{1}$, Muhammad Taufik ${ }^{1}$, and Kukuh Sudjatmiko ${ }^{2}$
}

\begin{abstract}
Abstrac-Water is natural resources that is very essential for living creatures and the environment. Along with the increase of population, will increase the water demand and reduce the area of free land / open green space for the formation of ground water. By considering soil water conservation aspects, it is necessary to conduct a study of the recharge area on water basin soil in Pasuruan. This study was to determine the condition of the recharge area in the Basin Groundwater Pasuruan in 2003 and 2014. So it will be $k[1]$ nown the changes of the vegetations density and land cover in the recharge area that can affect infiltration process in order to conserve water resources in CAT Pasuruan. From these changes it would be able to make the prediction of future conditions in the recharge area in CAT Pasuruan. This study uses Remote Sensing using Satellite imagery Landsat and Geographic Information System (GIS). Studies to determine the recharge area is influenced by several parameters, that is slope of land, lithology and Rainfall. Processing results obtained vegetation density changes of the recharge area in 2003-2014, high vegetation density decreased by $4330,89 \mathrm{Ha}$, so that changes in the high vegetation density in 2025 is predicted to be $52305,39 \mathrm{Ha}$ and become $52176,78 \mathrm{Ha}$ in 2030 . While land cover changes produce changes in forest land cover increased by $569,88 \mathrm{Ha}$, so that changes in forest land cover in 2025 is predicted to be $37563,88 \mathrm{Ha}$ and became $38720,494 \mathrm{Ha}$ in 2030. The relationship between vegetation density and land cover of the recharge area in $2003-2014$ obtained high vegetation density that experienced an increase area, which is on garden land cover amounting to 1144,80 Ha, 943,02 Ha of forest, 947,79 Ha of settlements land cover and 262,53 Ha of vacant land. And that experienced an increase with low vegetation density are the fields amounting to $943,02 \mathrm{Ha}$ and $277,47 \mathrm{Ha}$ of vacant land. Land cover vegetations that dominates throughout the recharge area is a mahogany tree vegetation, and sengon.
\end{abstract}

Keywords—Recharge Area, CAT Pasuruan, Remote Sensing.

Abstrak-Air adalah sumber daya alam yang sangat penting bagi makhluk hidup dan lingkungan. Seiring dengan bertambahnya jumlah penduduk, akan meningkatkan kebutuhan air dan mengurangi luas lahan bebas / open green untuk pembentukan air tanah. Dengan mempertimbangkan aspek konservasi air tanah, perlu dilakukan penelitian tentang daerah resapan air di lahan air di Pasuruan. Penelitian ini untuk mengetahui kondisi daerah resapan air di Perairan Basin Pasuruan pada tahun 2003 dan 2014. Sehingga akan diketahui perubahan kerapatan vegetasi dan tutupan lahan di daerah resapan yang dapat mempengaruhi proses infiltrasi untuk menghemat sumber daya air. di CAT Pasuruan. Dari perubahan tersebut maka akan dapat membuat prediksi kondisi masa depan di daerah resapan di CAT Pasuruan. Penelitian ini menggunakan Remote Sensing dengan menggunakan citra satelit Landsat dan Sistem Informasi Geografis (SIG). Studi untuk menentukan daerah resapan dipengaruhi oleh beberapa parameter, yaitu kemiringan lahan, litologi dan curah hujan. Hasil pengolahan diperoleh perubahan kepadatan vegetasi daerah resapan pada tahun 2003-2014, kepadatan vegetasi tinggi turun 4330,89 Ha, sehingga perubahan kepadatan vegetasi tinggi pada tahun 2025 diprediksi sebesar 5.2305,39 Ha dan menjadi 52176,78 Ha di 2030. Sementara perubahan tutupan lahan menghasilkan perubahan tutupan lahan hutan meningkat sebesar 569,88 Ha, sehingga perubahan tutupan hutan pada tahun 2025 diprediksi mencapai 37563,88 Ha dan menjadi 38720.494 Ha pada tahun 2030. Hubungan antara kepadatan vegetasi dan tutupan lahan daerah resapan pada tahun 2003 - 2014 memperoleh kepadatan vegetasi tinggi yang mengalami kenaikan luas, yaitu pada tutupan lahan kebun seluas 1144,80 Ha, 943,02 Ha hutan, 947,79 Ha tutupan lahan permukiman dan 262,53 Ha lahan kosong. Dan yang mengalami peningkatan dengan kepadatan vegetasi rendah adalah lahan seluas 943.02 Ha dan 277,47 Ha lahan kosong. Tanaman penutup tanah yang mendominasi sepanjang daerah resapan adalah vegetasi pohon mahoni, dan sengon.

Kata Kunci-Recharge Area, CAT Pasuruan, Remote Sensing.

\section{INTRODUCTION}

$\mathrm{W}$ ater is a natural resource that is essential to living creatures and the environment, including all the people of Indonesia. Along with the increase of population, will increase the water demand. Beside that,

${ }^{1}$ Isniyatus Sholikhah and Muhammad Taufik are with Department of Geomatics Engineering Institut Teknologi Sepuluh Nopember, Surabaya, 60111, Indonesia. E-mail: isniyatus@gmail.com, taufik_srmd@yahoo.com the building construction also leads to reduced of free land / open green space for the formation of ground water. It can be seen from ground water use in CAT Pasuruan which currently leads in the region that hydrogeologically was a recharge area. By considering aspects of soil water conservation it is necessary to

${ }^{2}$ Kukuh Sudjatmiko is with Departemen of Dinas Energi dan Sumber Daya Mineral Provinsi Jawa Timur. E-mail: kukuh.sudjatmiko@gmail.com 
conduct a study of the recharge area on water basin soil in Pasuruan. [1].

By considering aspects of soil water conservation it is necessary to conduct a study of the recharge area on water basin soil in Pasuruan. This study was to determine the condition of the recharge area in the Basin Groundwater Pasuruan in 2003 and 2014. So it will be known the changes of the vegetations density and land cover in the recharge area that can affect infiltration process in order to conserve water resources in CAT Pasuruan. From these changes it would be able to make the prediction of future conditions in the recharge area in CAT Pasuruan.

\section{METHOD}

Image data used in this research is Satellite Imagery Landsat $7 \mathrm{ETM}+$ and Landsat 8 at the public domain USGS (United States Geological Survey) http://earthexplorer.usgs.gov/ Path 118 and Row 65 of September $1^{\text {st }}, 2014$ and May 22 $2^{\text {th }}, 2003$ acquisition of the data.

Vector data used in this research geologic map of the malang and probolinggo, contour map of pasuruan district, raifall map of pasuruan district, and Basin Groundwater (CAT) map of jawa timur province.

The research location at Groundwater Basin region precisely at the administrative borders of Pasuruan (Figure 1).

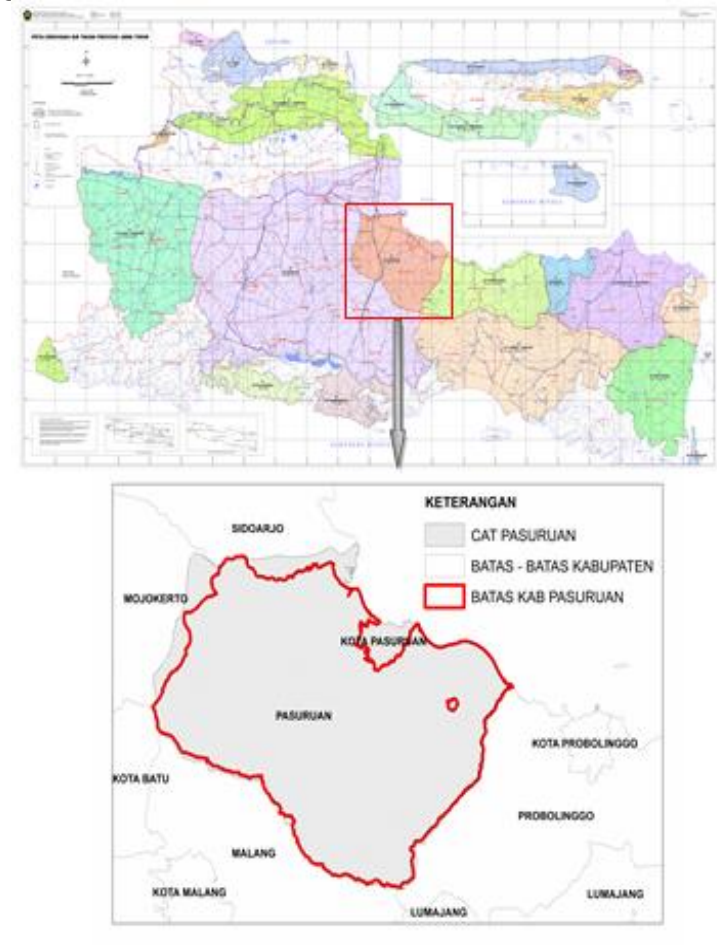

Figure 1. Map of Study Area

This study was to determine the condition of the recharge area in the Basin Groundwater Pasuruan in 2003 and 2014. So it will be known the changes of the vegetations density and land cover in the recharge area that can affect infiltration process in order to conserve water resources in CAT Pasuruan. From these changes it would be able to make the prediction of future conditions in the recharge area in CAT Pasuruan. This study uses Remote Sensing using Satellite imagery Landsat and Geographic Information System (GIS).

Data processing consists of determining the recharge area, land cover and the vegetation index. Determining recharge area is done by scoring the decisive parameters comprising the slope, lithology and rainfall. While the determination of the density of vegetation using vegetation index Normalized Difference Vegetation Index ( NDVI ) . NDVI has a function algorithm NDVI $=($ Rnir - Rred $) /($ Rnir + Rred $)$ [2] .The detailed procedure is shown with the help of flow chart in Figure. 2.

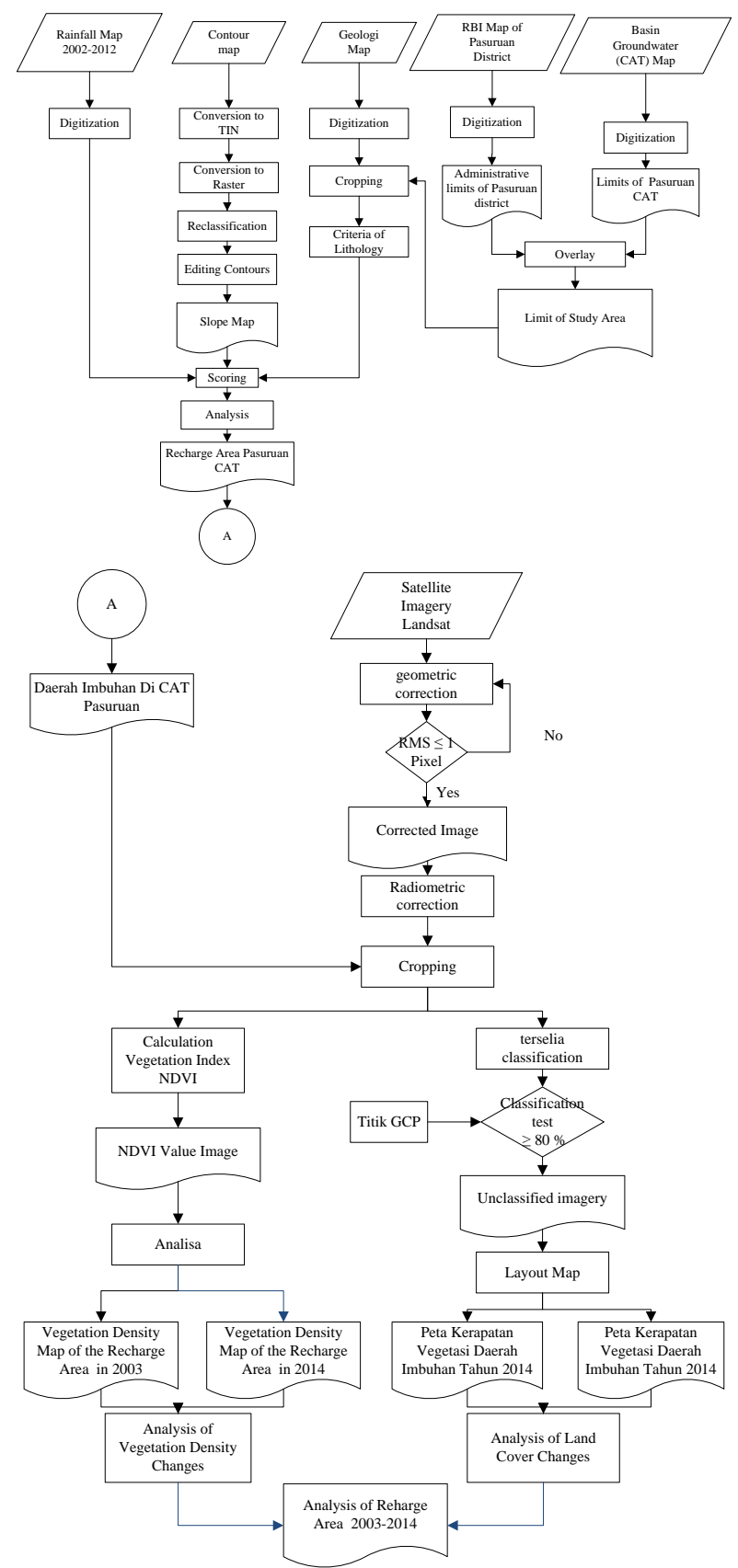

Figure 2. Flow chart showing detailed procedure

\section{RESULT AND DISCUSSION}

A. Determining Recharge Area 
Determination of recharge areas in Pasuruan CAT was influenced by several parameters, that is slope , lithology, and rainfall [3]. The procedure of determination recharge areas in Pasuruan is shown with the help of flow chart in Figure 3.

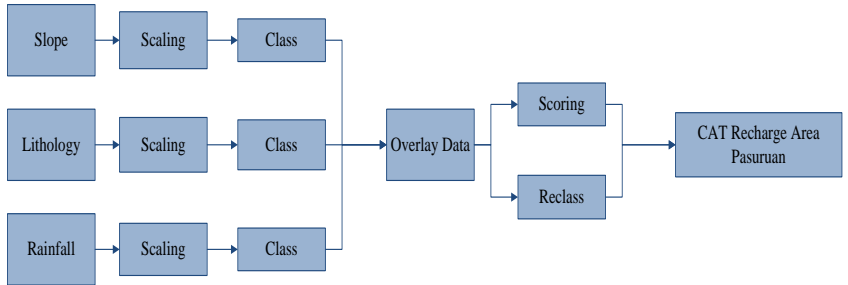

Figure. 3. Flow chart showing determination of recharge areas in Pasuruan CAT procedure.

a) Slope

The criteria of slope parameter is based Contour Map ( Figure 4).

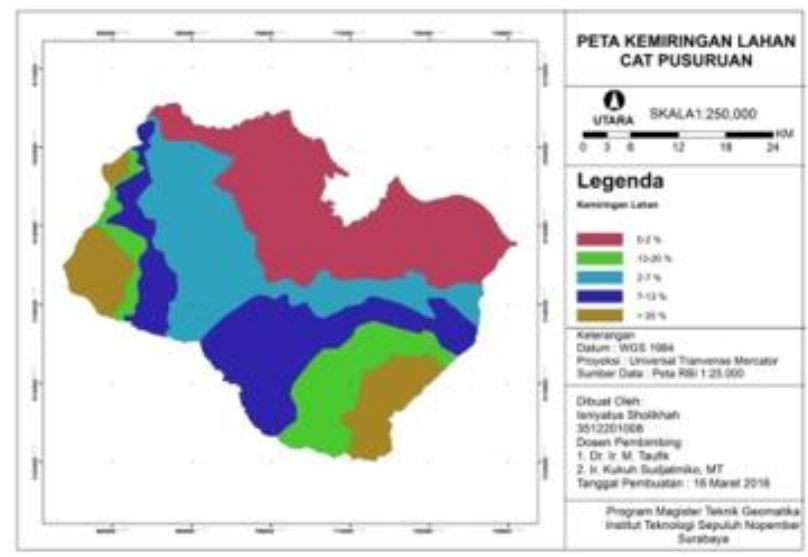

Figure 4. Slope Map of Pasuruan CAT

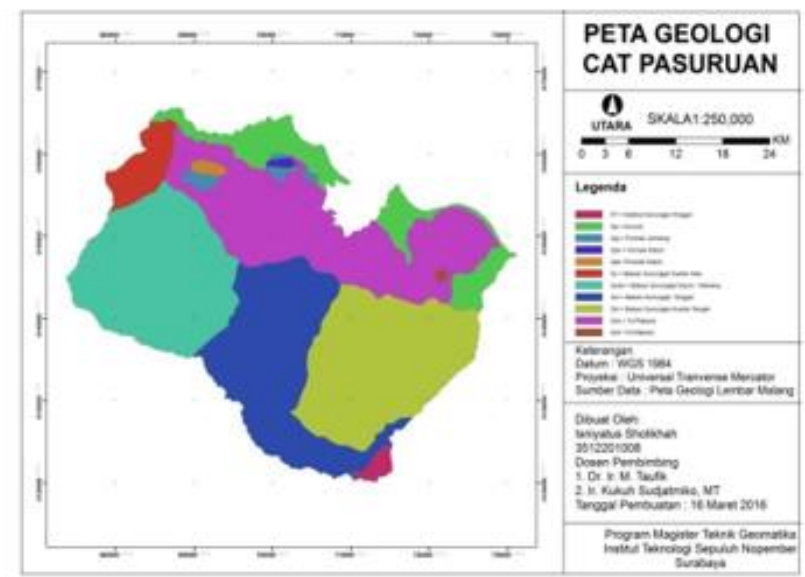

Figure 5. Geologic Map of Pasuruan CAT

\section{B. Vegetation Index}

Image processing results obtained SOF (Strength of Figure ) at 0.2576 and the result of geometric correction with registration technique "Select GCP : image to image" with 10 points on Landsat 7 ETM obtained 0,436027 RMSerror value and Landsat 82014 obtained 0,360314 RMSerror value . b) Lithology

The criteria of lithologi parameter is based Geologic Map ( table 1).

TABLE 1.

LEVELS RANGE DENSITY

\begin{tabular}{ccc}
\hline \hline Class & NDVI Range & Density Level \\
\hline 1 & $-1,0$ s.d 0,32 & Rare \\
2 & 0,32 s.d 0,42 & Medium \\
3 & $>0,42$ s.d 1 & High \\
\hline \hline
\end{tabular}

c) Rainfall Parameter

The criteria of rainfall parameter is based Geologic Map.

Determination of recharge areas in Pasuruan CAT is done by scoring with metode Overlay Weighted Sum method the decisive parameters comprising the slope, lithology and rainfall. The results of determination obtained main recharge areas, and, removable area ( Figure 6).

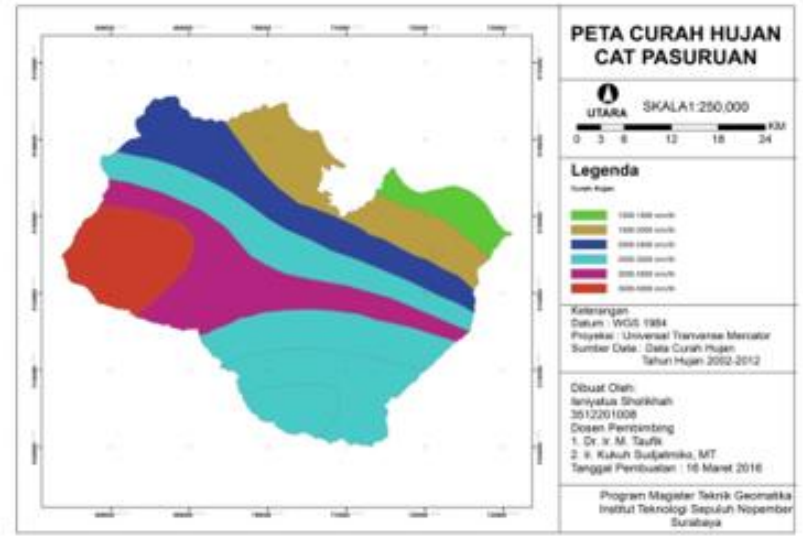

Figure 6. Rainfall Map of Pasuruan CAT

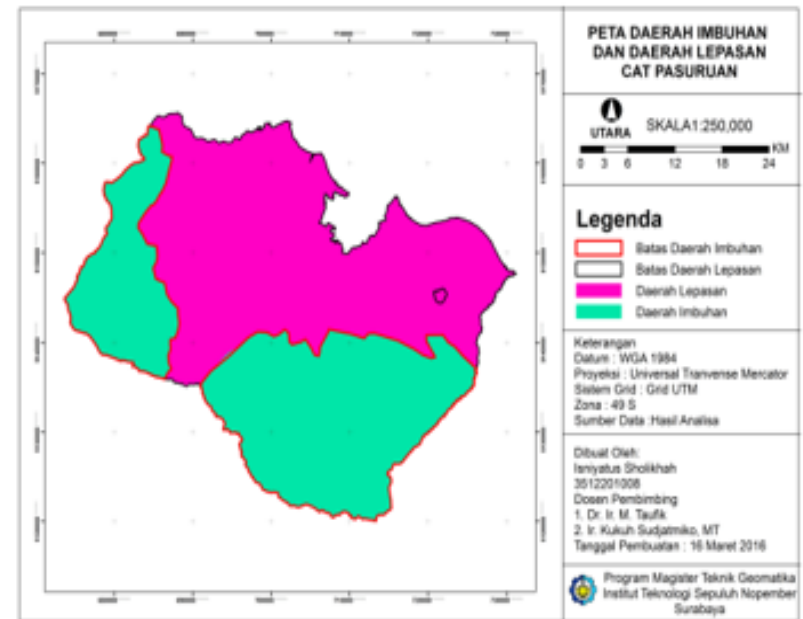

Figure 7. recharge area Pasuruan CAT

Geometric correction used to reduces radiometric errors in the image, as well as to cultivate the vegetation index algorithm that uses data from the image reflectance value.

Grading on the vegetation index NDVI algorithm refers to the Ministry of Forestry regulation of 2003 which divided the class into three classes NDVI, which is rare, medium, and high ( Table 1 ) [3] . 
TABLE 2.

THE RESULTS OF THE NDVI CLASSIFICATION

\begin{tabular}{|c|c|c|c|c|c|c|}
\hline \multirow{2}{*}{$\begin{array}{c}\text { Vegetation } \\
\text { Classificat } \\
\text { ion }\end{array}$} & \multicolumn{6}{|c|}{ Recharge Areas } \\
\hline & 2003 & 2014 & 2003 & 2014 & (Ha) & $(\%$ \\
\hline $\begin{array}{c}\text { Vegetation } \\
\text { Rare }\end{array}$ & $\begin{array}{c}4436,6 \\
4\end{array}$ & $\begin{array}{c}6404,7 \\
6\end{array}$ & 6,40 & 9,24 & $\begin{array}{c}1968, \\
12\end{array}$ & $\begin{array}{c}2,8 \\
4\end{array}$ \\
\hline $\begin{array}{l}\text { Vegetation } \\
\text { Medium }\end{array}$ & $\begin{array}{c}3885,6 \\
6\end{array}$ & $\begin{array}{c}6254,3 \\
7\end{array}$ & 5,61 & 9,03 & $\begin{array}{c}2368 \\
71\end{array}$ & $\begin{array}{c}3,4 \\
2\end{array}$ \\
\hline $\begin{array}{c}\text { Vegetation } \\
\text { High }\end{array}$ & $\begin{array}{c}60967 \\
17\end{array}$ & $\begin{array}{c}56636 \\
28\end{array}$ & $\begin{array}{c}87,9 \\
9\end{array}$ & $\begin{array}{c}81,7 \\
3\end{array}$ & $\begin{array}{c}- \\
4330, \\
89\end{array}$ & $\begin{array}{c}- \\
6,2 \\
6\end{array}$ \\
\hline Total & $\begin{array}{c}69289 \\
47\end{array}$ & $\begin{array}{c}69295 \\
41 \\
\end{array}$ & $\begin{array}{c}100 \\
00\end{array}$ & $\begin{array}{c}100 \\
00\end{array}$ & & \\
\hline
\end{tabular}

Processing results obtained vegetation density changes of the recharge area in 2003-2014, high vegetation density decreased by $4330,89 \mathrm{Ha}$

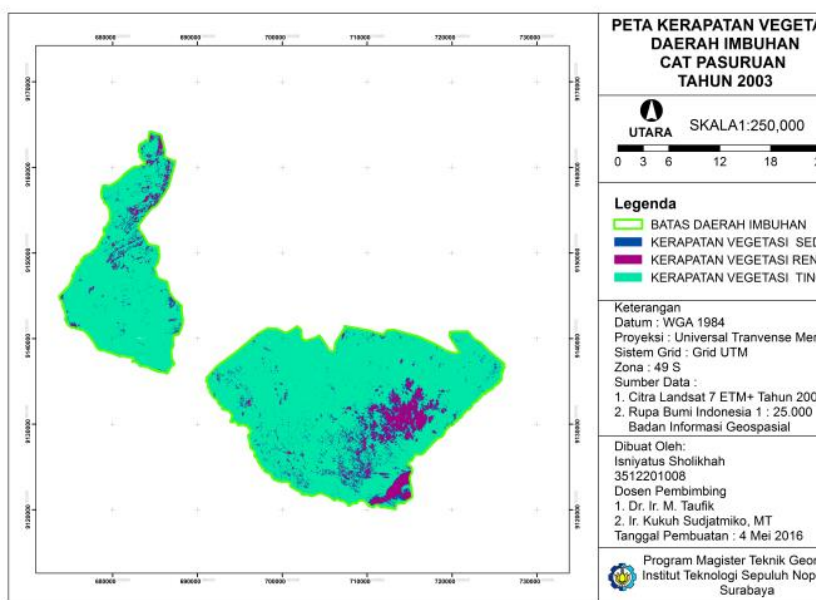

Figure 8. Processing Results of vegetation density 2003

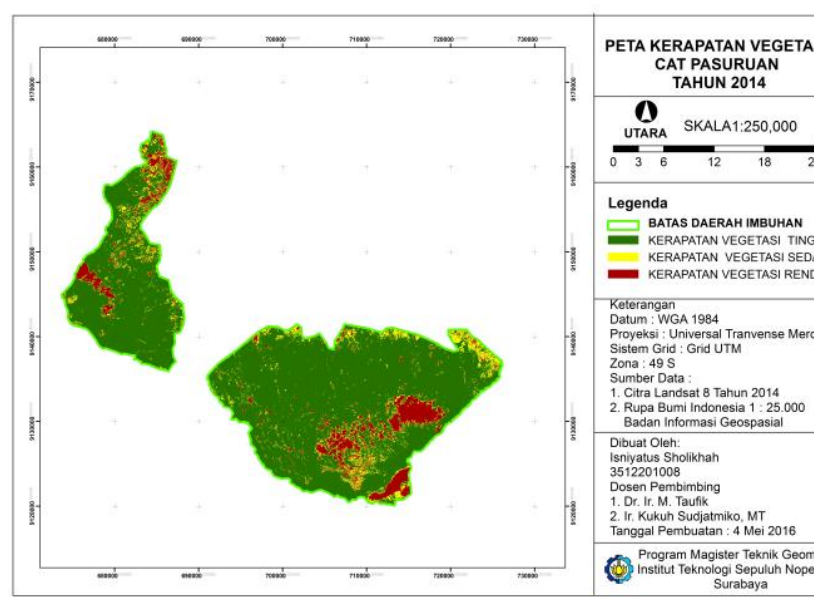

Figure 9. Processing Results of vegetation density 2014
To predict the condition of high vegetation density change in the future, may use linear regression equation $y=-4330 . x+65298$.

From the the linear regression equation, high vegetation density in 2025 is predicted to be 52305.39 ha and in 2030 became $52176.78 \mathrm{Ha}$.

The Results of recharge area classification based on NDVI values, presented in the map ( Figure 8 and Figure $9)$.

\section{Land Cover}

Land cover classification is done by the method of terselia classification, type maximum likellihood. Accuracy of processing land cover is calculated using confusion matrix and sample as many as 23 points, the tolerance limits given is $\geq 80 \%$. Confusion matrix calculations in 2003 amounted to $90.75 \%$ and in 2014 amounted to $98.45 \%$.

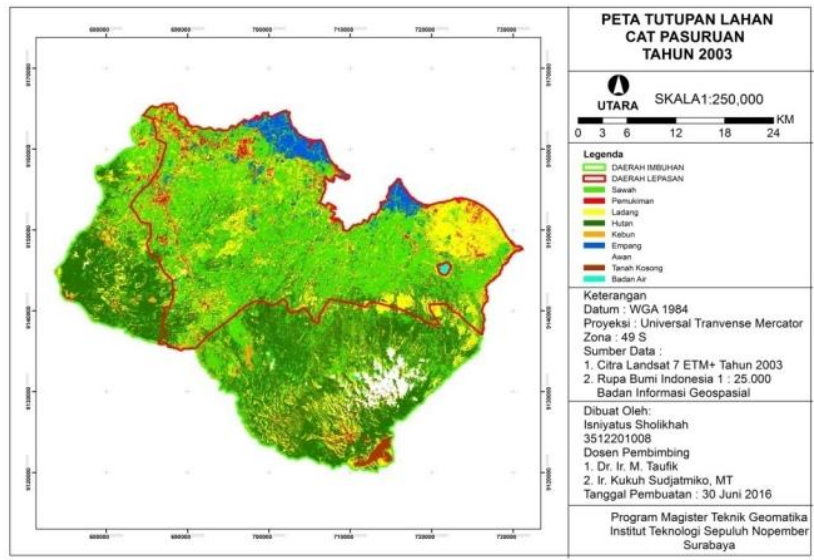

Figure 10. Processing Results of Land Cover 2003

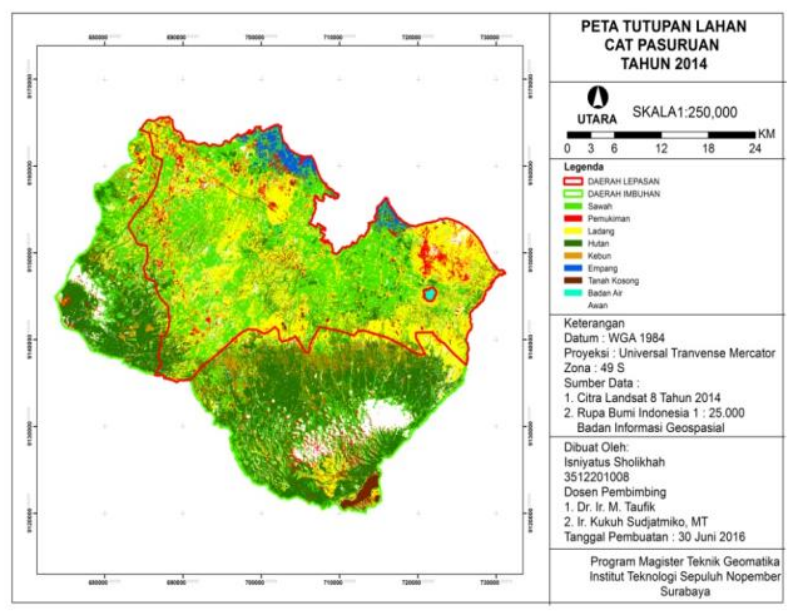

Figure 11. Processing Results of Land Cover 2014 


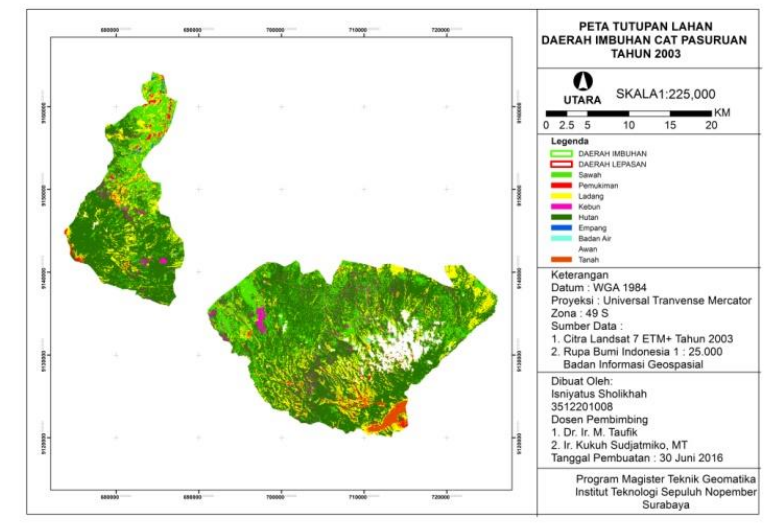

Figure 12. Land Cover of the recharge area 2003

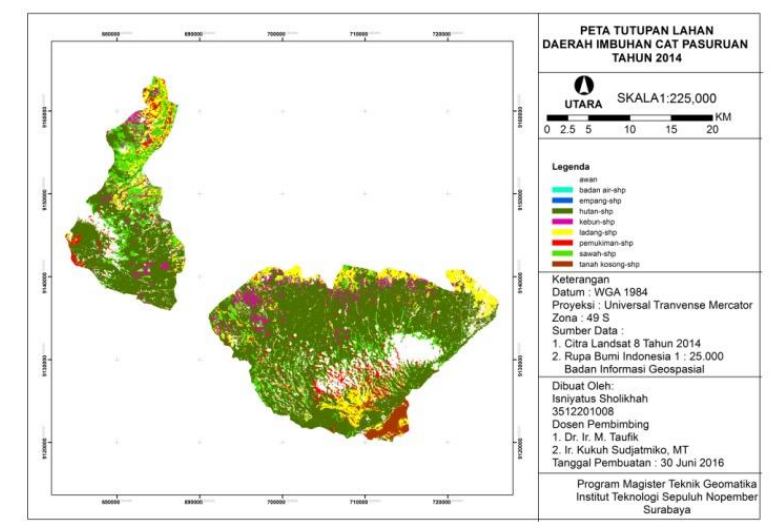

Figure 13. Land Cover of the recharge area 2014

The following table are land cover area calculations of recharge area in year 2003-2014 (table 3):

TABLE 3.

THE RESULTS OF THE LAND COVER CLASSIFICATION

\begin{tabular}{|c|c|c|c|}
\hline Classification & $\begin{array}{l}2003 \\
(\mathrm{Ha})\end{array}$ & $\begin{array}{l}2014 \\
(\mathrm{Ha})\end{array}$ & $\begin{array}{c}\Delta \\
\text { (Ha) }\end{array}$ \\
\hline Rice Fields & 13551,12 & 8643,87 & $-4907,25$ \\
\hline Settlements & 1297,17 & 2307,96 & 1010,79 \\
\hline Fields & 10607,04 & 6503,13 & $-4103,91$ \\
\hline Forest & 37563,48 & 38133,36 & 569,88 \\
\hline Garden & 2325,69 & 3547,08 & 1221,39 \\
\hline Pond & 114,48 & 14,85 & $-99,63$ \\
\hline Vacant Land & 1002,15 & 1845,99 & 843,84 \\
\hline Water & 87,75 & 3,87 & $-83,88$ \\
\hline Cloud & 2748,78 & 8643,87 & 5895,09 \\
\hline Total & 69297,66 & 69643,98 & \\
\hline
\end{tabular}

From the data processing, forest cover increased by $569.88 \mathrm{Ha}$. To predict changes in forest cover in the future may use linear regression equation $\mathrm{y}=569.8 \mathrm{x}$ +36994 .

From the the linear regression equation can be determined prediction changing conditions of forest cover in 2025 is predicted to be 37563.88 ha and in 2030 became $38720.494 \mathrm{Ha}$.

\section{Analysis of Recharge Area changes}

Analysis of reharge area changes obtained from the the relationship changes between land cover and vegetation density of recharge areas in years 2003-2014.

TABLE 4.

RECHARGE AREA CHANGES

\begin{tabular}{|c|c|c|c|}
\hline Classification & $\begin{array}{c}\text { Vegetation } \\
\text { Rare }\end{array}$ & $\begin{array}{c}\Delta \\
\text { Vegetation } \\
\text { Medium } \\
\text { (Ha) }\end{array}$ & $\begin{array}{c}\text { Vegetation } \\
\text { High }\end{array}$ \\
\hline Rice Fields & 24,03 & 51,21 & $-5321,43$ \\
\hline Settlements & $-53,19$ & 115,92 & 947,79 \\
\hline Fields & 794,34 & 1412,91 & $-6311,16$ \\
\hline Forest & $-100,80$ & $-271,80$ & 943,02 \\
\hline Garden & 4,14 & 72,45 & 1144,80 \\
\hline Pond & $-89,10$ & $-10,26$ & $-0,27$ \\
\hline Vacant Land & 277,47 & 301,68 & 262,53 \\
\hline Water & $-66,42$ & $-17,55$ & 0,09 \\
\hline Cloud & 1177,56 & 713,43 & 4004,19 \\
\hline Total & & & \\
\hline
\end{tabular}

From data processing, obtained the high vegetation density that increased are: Gardens of 1144.80 hectares, 943.02 hectares of forest, settlement of 947.79 hectares and 262.53 hectares of vacant land.

And at the low density that was increase are fields amounted to 943,02 hectares, vacant land of 277.47 hectares, and clouds. Land cover vegetation that dominates in all recharge area are mahogany and sengon trees.

High vegetation density increases in forest land, this suggests that the reforestation of forest areas capable of increasing the density of vegetation on forest land cover.

In addition, the increase also occurred on garden land, this indicates that the increased activity of production and planting vegetation in an effort to protect the soil surface from the impact of rain water, runoff decrease, hold soil particles through the root system and maintain stability in the soil's capacity to absorb water.

On the one hand there is an increase in the area with low vegetation density with land cover of settlement and vacant land, this indicates that there is a land conversion that could threaten the sustainability of water resources.

\section{CONCLUSION}

Based on the results and analysis, it can be concluded:

a) Based on the analysis it was concluded that the determination of the recharge area obtained zones is the recharge area and loose areas.

b) Processing results obtained vegetation density changes of the recharge area in 2003-2014, high vegetation density decreased by $4330,89 \mathrm{Ha}$

c) High vegetation density in 2025 is predicted to be $52305,39 \mathrm{Ha}$ and become 52176,78 Ha in 2030.

d) Processing results obtained land cover changes of the recharge area in 2003-2014, land cover forest increased by $569,88 \mathrm{Ha}$.

e) To predict the future of forest change can use the linear regression equation $\mathrm{y}=569.8 \mathrm{x}+36994$. 
f) With the linear regression equation, changes in forest cover in 2025 is predicted to be 37563.88 ha and in 2030 became $38720.494 \mathrm{Ha}$.

g) The relationship between vegetation density and land cover of the recharge area in 2003 - 2014 obtained high vegetation density that experienced an increase area, which is on garden land cover amounting to 1144,80 Ha, 943,02 $\mathrm{Ha}$ of forest, 947,79 $\mathrm{Ha}$ of settlements land cover and 262,53 Ha of vacant land. And that experienced an increase with low vegetation density are the fields amounting to $943,02 \mathrm{Ha}$ and $277,47 \mathrm{Ha}$ of vacant land.

h) Land cover vegetations that dominates throughout the recharge area is a mahogany tree vegetation, and sengon.

\section{REFERENCES}

[1] Dinas Energi Dan Sumber Daya Mineral Provinsi Jawa Timur, "Pemetaan Pengambilan Air Tanah Pasuruan," 2012.

[2] T. M. Lillesand and R. W. Kiefer, Remote Sensing and Image Interpretation. New York: Wiley \& Sons, 2000.

[3] Badan Geologi, "Panduan Teknis Pengelolaan Air Tanah," Bandung, 2007.

[4] Abdurrahman, R.S, "Studi Hidrologi Mataair di Kabupaten Kuningan. Jawa Barat”, Fakultas Geografi Universitas Gadjah Mada : Yogyakarta, 1990.

[5] Asy'Ari, Imam, "Evaluasi Kondisi Pemanfaatan Airtanah Di Kabupaten Pasuruan", ITS-Surabaya, 2005.

[6] Asdak, C, "Hidrologi dan Pengelolaan Daerah Aliran Sungai", Yogyakarta: Gadjah Mada University Press, 2004.

[7] Bowles, J.E, "Sifat-Sifat Fisis dan Geoteknis Tanah (Mekanika Tanah)", Jakarta : Erlangga, 1986.

[8] Danaryanto et al, "Air Tanah di Indonesia Dan Pengelolaannya. Ditjen Geologi Dan Sumber Daya Mineral", Departemen Energi Dan Sumber Daya Mineral, 2005.

[9] Departemen Kehutanan, "Peraturan Menteri Kehutanan Republik Indonesia nomor: P.32/MENHUT-II/2009”, Jakarta, 2009.

[10]Dinas ESDM, "Identifikasi Pengolahan Dan Pemanfaatan Air Bawah Tanah Di Kabupaten Pasuruan", Jawa Timur:Surabaya, 2008.

[11]Prahasta, Edi, "Konsep-Konsep Dasar Sistem Informasi Geografis", Bandung: Informatika Bandung, 2002.

[12]Karnieli, A., Agam, N., Pinker, R., Anderson, M., dan Goldberg, A, "Use of NDVI and Land Surface Temperature For Drought Assesment", Journal of Climate, Vol.24, hal. 619, 2009.

[13]Kodoatie, RJ, "Pengantar Hidrologi”, Andi Yogyakarta: Yogyakarta, 1996

[14]Kodoatie, R.J., dan R. Sjarief," Tata Ruang Air" Yogyakarta: ANDI, 2010.

[15]Maria, Rizka, dkk, "Pengaruh Penggunaan Lahan Terhadap Fungsi Konservasi Air Tanah Di Sub Das Cikapundung", LIPI : Riset Geologi dan Pertambangan, 2014.

[16]Murtono, Teggu, dkk, "Zonasi Imbuhan Air Tanah Pada Daerah Aliran Sungai Lahumbuti Provinsi Sulawesi Tenggara", Universitas Hasanudin : Geosains, 2013.

[17]Noor, Djauhari, "Geologi Untuk Perencanaan", Graha Ilmu: Yogyakarta, 2011.

[18] Seyhan, Ersin, "Dasar-Dasar Hidrologi", Gadjah Mada University Press: Yogyakarta, 1977.

[19]USGS, "Using the USGS Landsat 8 Product", 2003, History :http://landsat.usgs.gov/Landsat8_Using_Product.php accessed on 13 December 2015.

[20]Wedehanto, Sony, "Pengembangan Citra Landsat 7 ETM Untuk Menduga Keberadaan Air Tanah", FTSP - ITS, 2006.

[21]Wibowo, Mardi, "Model Penentuan Kawasan Resapan Air Untuk Perencanaan Tata Ruang Berwawasan Lingkungan”, Jakarta : Badan Pengkaji dan Penerapan Teknologi, 2006.

[22]Wilson, EM, "Hidrologi Teknik", ITB : Bandung, 1993.

[23]Wolf, Paul R, "Elemen Fotogrametri dengan Interpretasi Foto Udara dan Penginderaan Jauh", Gadjah Mada University Press, Yogyakarta,1993.
[24]Zuidam, R.A. Van., "Aerial Photo-Interpretation Terrain Analysis and Geomorphology Mapping". Smith Publisher The Hague, ITC, 1985. 